\title{
Challenge of Academic Paper as a Solution to Fulfilling Legal Needs in the Community
}

\author{
Rica Anggraeni \\ \{cha2_khan@yahoo.com\} \\ Pancasila University, Jalan Raya LentengAgungTimur No.56-80, SrengsengSawah, Jagakarsa, Kota \\ Jakarta Selatan, Daerah KhususIbukota Jakarta 12640, Indonesia
}

\begin{abstract}
It cannot be denied that Indonesia is a pluralistic country. Tribes, religion, and culture spread throughout in Indonesian archipelago with their unique characteristics. Pluralism in Indonesia, in the end, must be a subject at the legal unification as consequences from the development of the modern state, namely carrying legal certainty by making it happen in writing in the form of legislation to regulate all aspects of the life of nation and state. Of course, the operational basis for the governing all lies on the law. Legislation process in Indonesia is currently based on Law No. 12 the Year 2011, which sets the necessity of academic paper for the process of legislation. An academic paper is a research result which can be justified scientifically, and it will become a solution for the problems handled with the law. However, the laws generated through the results of research as outlined in the academic papers were not able to demonstrate significant quality. This can be seen from the number of filling judicial reviews to the constitutional court, which final decision is canceled. Based on that, it is questionable whether the academic papers the legislative process has been able to answer the material content of the law in meeting the needs of the law in the community or not. Then, what kind of formation of academic papers that can comply with these legal needs? This research uses doctrinal legal research because it not only examines the legal norms but also understands the concept of law as a norm.
\end{abstract}

Keywords: Academic Paper, Legal Research Method, Law-making

\section{Introduction}

The state in the modernization context has no simple role. The state has a very complex role in the lives of its people. The influence of the concept of a state based on the law whatever it is - both rechtsstaats and the rule of law-make the state has a role by making law as a regulation in the life process of nation and state. The law is drawn in to engage in limiting and regulating all the forces and interests that exist in society. The law in its emergence becomes the guide of behavior for all people in a territory without exception, and it is not always accepted[1] because the law constituting the arrangement becomes the domain of the state in its formation process.

When the law becomes a state domain in its formation, the law becomes something rational and formal. The logical consequence with such a law is that law is known only as a textual document that ultimately contains the norms that reconstruct society. Therefore, such a law is not readily accepted by the pluralistic Indonesian society. Such a law is indeed the trademark of modernity which requires a stable, efficient, and technocratic government. Everything in modernization must be able to rely on continuity, trustworthiness, objectivity of the rule of law, and a rational way of working that can be predicted[2].

Indonesia itself is a country that flows in the concept of the state based on modern lawread modernity-which puts the law as a qualified tool to regulate all life of nation and state. 
This also has been stated in the Constitution of Indonesia through Article 1 paragraph (3) of the 1945 Constitution of the State of the Republic of Indonesia, which declares that everything in Indonesia is always regulated by law in the concept of norms contained in the legislation.

Regarding the legislation, with the conscience as a country that is very dependent on legislation, Indonesia already has guidelines in the process of formulating legislation. Currently, Indonesia is subject to Law Number 12 the Year 2011 on the Establishment of Legislation.

Law Number 12 the Year 2011 on the Establishment of Legislation stipulates that academic texts must accompany the formation of laws, so that the Draft Law coming from the House of Representatives (DPR), the President, and the Regional Representative Council (DPD) must be accompanied with that. Interestingly, the existence of academic texts in the legislative process is not of significance to the quality of legislation produced by legislators. Especially with the phenomenon of the material test to the Constitutional Court so instantly, the law finds its validity. The number of judicial review of the Constitutional Court is increasingly increasing. It can be seen from the graph as follows:

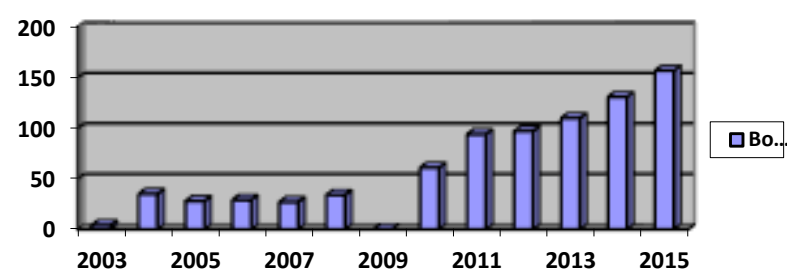

Also, the materials for law regulations are very loose in the context of the fulfillment of legal needs in the community. With this, the law can regulate anything for the context of the fulfillment of legal needs in the community. Therefore it is raised a question: (1) Can these academic papers in the fulfillment of the process of law formation answer the intended content of the law about the fulfillment of legal needs in the community?; and (2) How can the academic papers fulfill such legal needs?

\section{Methodology}

The problem will be solved using the method of doctrinal law research. This approach is used because the legal concept used in this study is the norm. About the approach used, the data used are secondary data derived from primary and secondary legal materials. These materials are obtained by library data collection method. The primary legal materials are "all rules of law established and formally established by a state institution and a governmental body for the sake of appointment to be pursued based on force officially exercised by the state apparatus." Such as the Constitution of the State of the Republic of Indonesia Year 1945 and Law Number 12 the Year 2011 on the Establishment of Legislation. The secondary legal substances used in this study are data from the official website of the Constitutional Court, as well as secondary legal materials as the builders of understanding such as books written by SoetandyoWignjosoebroto, Mahfud MD, and Anthon F. Susanto. The material collected in the data will be analyzed by using qualitative methods based on inductive reasoning. 


\section{Findings}

\subsection{Addressing the Challenges of Compliance with Legal Needs of People in Academic Manuscripts}

Based on the type of legislation, the type of law is a type of legislation that becomes the backbone of the implementation of state management and implementation. Therefore, the law becomes an operational basis for the government to take action as well as a direction for the government and society to conform to those outlined by the 1945 Constitution of the State of the Republic of Indonesia. Due to its function, the process of formulating the law is regulated in such a way through Law Number 12 the Year 2011 on the Establishment of Legislation, one of which is through the planning process as outlined in the National Legislation Program (Prolegnas).

When knowing about what should be contained in Prolegnas, the classified material and its relation to other legislation, which is the description of the Draft Law conception, must have been through assessment and alignment as outlined in the Academic Paper. It means Academic Paper should already exist and accompany the legislative process since the planning stage does not only begin when drafting.

The Academic Paper is a "text of the results of research or legal assessment and other research results on a particular problem that can be scientifically accountable for the regulation of the problem in a Draft Law, the Draft of Provincial Regulation, Draft of Regency/City Regulation, and as solutions to community issues and legal needs."

As a result of research and assessment, the academic paper should pave the way and find accuracy to understand the problems of legal needs in society that must be met and solved through a form of law. Therefore, the research process undertaken in making an academic paper must be a qualified research process. That is, it is not something that is only made to fulfill a mere formality but is made to find a solution. The quality and competence of academics will be tested in the formation of this academic paper through research processes to find answers to a community's legal concerns or needs.

The needs of the intended public law have a full meaning so that it can be interpreted whatsoever as to the legal needs of the community, which ultimately does not rely on solving social problems. Indications can be known through the context of understanding the needs themselves.

Needs termed with need in English are defined as "objective conditions that state the presence of necessity in some subjects belonging to the leader to immediately obtain some resources to enable the survival of their existence."[3]

Needs are not just a desire (wants). It is far different from it. Desire is "a subjective condition that is perceived as urgent as stated by a number of lay subjects to obtain resources to satisfy their needs, and at the same time to alleviate the unrest."[3]. Necessarily, desire is based on gratification, while the need rests on "something very, very necessary, and that is for the long term." Thus, because the need is something that must be met to maintain the existence of a person or group of people for an extended period, then to find it out an analysis is needed in order to draw insights into macro situations.

\subsection{Formation of Academic Paper that Can Meet Legal Needs in Society}

The law will be a solution or way out of the problems encountered in the life of the nation, state, and society. Legal norms in the law will establish a system to resolve problems that occur. The legal norms in law surely will raise different perceptions in various circles of 
Indonesian society, even though the texts that manifest as legal norms are formed by the legislator as a tool or instrument to change the behavior of society to match what the state has to say.

Perception errors cause incompleteness and disability. This term is coined because lawmakers are unable to formulate precisely what is in the community. Overcoming that, most people then regarded it as an exact formula, while still allowing open spaces for the gap of differences in perception. [4].

Research methods based solely on the juridical normative or merely empirical-with the sociolegal term-certainly have a dominant relevance to the quality of the resulting legislation. The content of the law, one of which is to "meet the needs of the law in society," will not be "fulfilled" only by capitalizing on normative juridical or just empirical research methods. Such methods make the science of law used as the basis of the logic of lawmakers in formulating the text of legal norms in the laws are textual, closed, and rigid.

This is because normative juridical research methods are more focused on norms or textual and primarily serve only to meet the demands of legal presence in the concept of legislation. This study "retains the applicable law and studies it rationally." This study ignores reality and qualifies as a narrow and closed view. This study also has a dualist-hierarchical character that separates the subject-objects, and places the subject superior to the object, thereby generating the subject's exploitation of reality which is seen as something that can be treated as it pleases.

As an extensive system and reduce the values and interests of the people, the law in its formation according to Law Number 12 the Year 2011 on the Formation of Legislation must be followed by Academic Paper. This Academic Paper is a result of research or study that offers a solution to the legislators regarding the problems or legal needs of the community. However, the academic paper is more often understood as a formality to fulfill the obligations set out in the formation of laws, so its content is only to adjust the material to be regulated in legislation without the use of in-depth research methods.

The research methods offered in the guidelines for the establishment of legislation for the establishment of laws are only legal research or other research. Legal research can also be done with a combination of two methods of juridical normative and empirical juridical termed in this context with socio-legal and using normative juridical research only. With this method of research, it would be challenging to produce a comprehensive study or study that can describe the solution to the problem or the legal needs of the community. Therefore, it takes seriousness from academia to conduct bridging research and study and lawmakers in response to the results of studies and research offered by academics, so that the results of the research are significantly used to provide solutions to the problems[5].

While in empirical juridical or termed sociolegal research in Appendix I of Law Number 12 Year 2011 on the Establishment of Legislation, this only revolves around the concept of empirical juridical research that begins with normative research or review of laws and regulations followed by observation depth and dissemination of the questionnaire to obtain the relevant non-legal factor data and which affect the legislation under study. This text still describes a monodisciplinary study based on normative juridical research. However, in the study of this model, norms are studied in a sociological perspective in its form as a social fact[3]. This study listens to the norm as the regularity of behavior in a society. However, this research method is sometimes operated in statistical measurements and techniques. Social phenomena are absorbed as a region that must be translated into numbers that affect each other. 
In the formation of Academic Paper, it should not only be limited to the science of ansich's law but must "crossover," open space for other sciences as an approach in the formation of values for the norms outlined in the law. Academic texts should comprehensively describe the situation in society and even reach the future in an ideal way, and be able to provide alternatives as solutions to solve problems without being contaminated with personal and group interests in the form of party or party.

Therefore, Academic Paper is not prepared for the sake of instantaneous, immediate needs, or because of inadequate thinking, so the preparation of Academic Paper should be done with in-depth and comprehensive research.

Through Academic Paper also, according to the researchers, borrowing the term used by Luc J. Wintgens is an attempt to bring de lege lata and de referenda [7]. De lege lata can be interpreted the same as law in the books. That is, it only takes into account the favorable laws in the binding legal norms in a legal system. While de referenda try to reflect other aspects outside the "eyesight" of law in general[7]. With this understanding, de referenda are the law seen through other approaches [7]. Thus, Academic Paper is the basis of scientific studies and justification of the establishment of regulations on issues that require regulation in the society. Hence, community involvement becomes an essential element in the preparation of Academic Paper. This community engagement is intended to enable the Academic Paper to capture legal needs that exist within the society as a sociological footing that underlies the thinking framework of norms[6].

\section{Conclusion}

Based on the results of the above study, it can be concluded that:

1. An academic paper in its formation can only answer the challenge as a solution for the problems or legal needs of the community if the research process undertaken in making an academic script uses a qualified research process. That is, it is not something that is only made to fulfill a mere formality but is made to find a solution.

2. The formation of academic paper can meet the fulfillment of legal needs in the community if academia is serious in conducting research and bridging the studies and the legislators in response to the results of studies and research offered by academics, so the results of significant research are used to provide Solution to the problem. Therefore, the Academic Paper should comprehensively describe the situation in society and even reach the future in an ideal way, and it should be able to provide alternatives as a solution to solve the problems.

\section{References}

[1] E. C. Ip, "Globalization and the future of the law of the sovereign state," Int. J. Const. Law, 2010.

[2] J. O. Fatile, I. Olojede, and K. D. Adejuwon, "Techno-Bureaucratic Governance and Public Service Delivery: Indonesia and Nigeria in Perspectives," Africa's Public Serv. Deliv. Perform. Rev., 2015.

[3] J. Delbrück, "Max Huber's sociological approach to international law revisited," Eur. J. Int. Law, 2007.

[4] E. Estévez, M. Rachitskiy, and C. Rodríguez, "Is perception of the mainstream legal system homogeneous across ethnic groups?," Eur. J. Psychol. Appl. to Leg. Context, 2013. 
[5] V. Tumonis, "Legal Realism \& Judicial Decision-Making," Jurisprudencija, 2012.

[6] A. Wiener and U. Puetter, "The quality of norms is hat actors make of it: critical constructivist research on norms," Int. Law Int. Relations, 2009.

[7] Witgens, Luc, J., 2013.The Rationality and Justification of Legislation: Essay in Legisprudence.(Switzerland: Springer International Publishing) 